\title{
Preservation of Incretin Activity After Removal of Gastric Inhibitory Polypeptide (GIP) from Rat Gut Extracts by Immunoadsorption
}

\author{
R. Ebert, H.Unger and W.Creutzfeldt \\ Division of Gastroenterology and Metabolism, Department of Medicine, University of Göttingen, Göttingen, FRG
}

\begin{abstract}
Summary. The action of watery rat gut extracts on glucose-induced insulin release in anaesthetized rats was examined before and after removal of GIP by immunoadsorption. Infusions of GIP-containing rat gut extracts nearly doubled the insulin release induced by intravenous glucose $\left(1 \mathrm{~g} \cdot \mathrm{kg}^{-1}\right.$. $\left.\mathrm{h}^{-1}\right)$. Peak insulin secretion was $98 \pm 11 \mathrm{mU} / 1$ (mean \pm SEM) after intravenous glucose and increased to $178 \pm 16 \mathrm{mU} / \mathrm{l}$ following infusion of glucose plus gut extract $(p<0.005)$. After injection of GIP antiserum in sufficient amounts to neutralize the GIP activity in the gut extract preparation, the additional
\end{abstract}

insulin release due to the gut extract was reduced by only $30 \%$. After complete removal of GIP from gut extracts by immunoabsorption, more than $50 \%$ of the incretin effect remained. These data suggest that the insulinotropic activity of rat gut extracts can only be partially related to GIP. The existence of additional insulinotropic gut factors which may also be released following oral glucose is postulated.

Key words: GIP, insulin, incretin, enteroinsular axis, rat gut extract, intestinal hormones.
Since the work of La Barre et al. [1], it has been known that the duodenum contains factors which can lower elevated blood glucose levels. In 1964 it was shown that more insulin is released after oral glucose loads than after intravenous infusion of the same amount of glucose despite a smaller rise of the blood glucose [2-4]. The intestinal insulinotropic factor was named 'incretin' by La Barre and the connection between the gut and the endocrine pancreas subsequently called the "entero-insular axis' [5].

Among various proposed hormonal factors of the entero-insular axis, the gut hormone, gastric inhibitory polypeptide (GIP) (now commonly referred to as glucose-dependent insulinotropic polypeptide) has become the main incretin candidate [6]. This hormone augments glucose-induced insulin secretion in vivo [7, $8]$ and in vitro $[9,10]$. GIP is released from endocrine cells present in the upper small intestine in response to oral, but not intravenous glucose [11].

The relative importance and physiological role of GIP as an incretin factor has been evaluated by experimental induction of GIP deficiency through intravenous injection of specific GIP antibodies during an oral glucose load in rats $[6,12,13]$. Following treatment with GIP antibodies, the insulin response to an intraduodenal glucose load was reduced; however, GIP antiserum did not completely abolish the incretin effect of the intraduodenal glucose load [13]. This suggests that GIP is not the only incretin factor.

Since the nervous system also influences glucose-induced insulin secretion following an oral or intraduodenal glucose load $[14,15]$, the preserved incretin effect after GIP antiserum injection could be related to the neural part of the entero-insular axis. To circumvent neural effects, the insulinotropic potency of differently prepared gut extracts can be studied. We report on the insulinotropic action of gut extracts after GIP antiserum injection and after removal of GIP from gut extracts by immunoadsorption.

\section{Materials and Methods}

Male Wistar rats weighing 250-350 g kept on a standard diet (Altromin, Firma Altromin, Lage, FRG) were used. After a $20 \mathrm{~h}$ fast, the animals were anaesthetized by IP injection of sodium pentobarbital $(50 \mathrm{mg} / \mathrm{kg}$ body weight). Plastic catheters with an internal diameter of $0.44 \mathrm{~mm}$ were placed in one carotid artery and the contralateral jugular vein. The catheters were fixed by ligature and kept open by slow infusion of saline $(1.5 \mathrm{ml} / \mathrm{h})$. One catheter was used for blood sampling while, on the opposite side, glucose and/or gut extract was infused. Body temperature of the animals was kept constant at $38^{\circ} \mathrm{C}$ throughout the experiments by means of an electric heating pad. After a 45-min recovery period, the experiments were started. The recovery period was necessary because basal immunoreactive GIP levels were elevated immediately after operation (range: $300-700 \mathrm{pg} / \mathrm{ml}$ ) and decreased to $100-300 \mathrm{pg} / \mathrm{ml}$ during the recovery period. In all experi- 
ments, blood was collected into ice-chilled heparinized tubes containing $1000 \mathrm{KIU}$ aprotinin/ml (Bayer, Leverkusen, FRG), centrifuged at $1500 \mathrm{~g}$ for $10 \mathrm{~min}$ and the plasma removed and frozen in aliquots.

\section{Comparison of the Insulinotropic Effect of Rat Gut Extract Before and After Removal of GIP by Immunoadsorption}

Glucose, dissolved in $0.154 \mathrm{~mol} / 1$ saline solution, was infused at a constant rate of $1 \mathrm{~g} \cdot \mathrm{kg}^{-1} \cdot \mathrm{h}^{-1}$ over $90 \mathrm{~min}$ in male Wistar rats $(n=12$, mean weight $284 \mathrm{~g}$, range $265-320 \mathrm{~g}$ ). In a second group of rats $(n=12$, mean weight $279 \mathrm{~g}$, range $250-290 \mathrm{~g}$ ), the same glucose load was combined with rat gut extracts, also dissolved in physiological saline solution. The gut extract was adjusted to give an infusion rate of $37 \mathrm{mg}$ protein $\cdot \mathrm{kg}^{-1} \cdot \mathrm{h}^{-1}$ corresponding to $0.9 \mu \mathrm{g}$ immunoreactive $\mathrm{GIP} \cdot \mathrm{kg}^{-1} \cdot \mathrm{h}^{-1}$. A third series of 12 rats (mean weight 293 , range $270-330 \mathrm{~g}$ ) received the IV glucose load together with immunoadsorbed rat gut extract. Again, the gut extract was adjusted to give an infusion rate of $37 \mathrm{mg}$ protein $\cdot \mathrm{kg}^{-1} \cdot \mathrm{h}^{-1}$. For practical reasons, on each day experiments were performed in two rats of each group. Blood samples $(0.4 \mathrm{ml})$ were taken before and 10,30,60 and $90 \mathrm{~min}$ after the start of the glucose infusion. Before drawing the blood, the saline from the dead space of the catheter lumen was discarded. Blood glucose levels were measured from the tail vein at $10 \mathrm{~min}$ intervals.

\section{GIP Antiserum Application Before Infusion of Rat Gut Extract}

Rabbit GIP antiserum (GÖ 5/76/9) raised in our laboratory [21] was injected as a bolus $(0.3 \mathrm{ml}) 60 \mathrm{~min}$ before the combined glucose $(1 \mathrm{~g}$. $\left.\mathrm{kg}^{-1} \cdot \mathrm{h}^{-1}\right)$ and gut extract $\left(37 \mathrm{mg}\right.$ protein $\left.\cdot \mathrm{kg}^{-1} \cdot \mathrm{h}^{-1}\right)$ infusion in nine rats (mean weight $309 \mathrm{~g}$, range $260-340 \mathrm{~g}$ ). A control group (mean weight $287 \mathrm{~g}$, range $250-350 \mathrm{~g}$ ) received $0.3 \mathrm{ml}$ rabbit serum instead of GIP antiserum followed by IV glucose alone. In a third control group (mean weight $315 \mathrm{~g}$, range $285-350 \mathrm{~g}$ ) $0.3 \mathrm{ml}$ normal rabbit serum was also given followed by infusions of gilucose and rat gut extract. Blood samples were drawn at $0,10,30,60$ and $90 \mathrm{~min}$. At $10 \mathrm{~min}$ intervals, blood glucose was measured from the tail vein. Blood samples for measurement of GIP-binding capacity were taken at the end of each experiment.

\section{Preparation of Rat Gut Extract}

The duodenum and the proximal part of the jejunum were resected, rapidly rinsed in ice-cold saline solution, plunged into chilled acetic acid $(0.2 \mathrm{~mol} / \mathrm{l})$ and homogenized for $30 \mathrm{~s}$ (Ultra-Turrax, Janke \& Kunkel, Stauffen, FRG). The homogenized extract was boiled for $15 \mathrm{~min}$, cooled at $4^{\circ} \mathrm{C}$ and centrifuged $(2000 \mathrm{~g}$ for $20 \mathrm{~min}$ ). Supernatant solutions were lyophilized to 1.33 Pascal and stored at $-20^{\circ} \mathrm{C}$ before analysis. The lyophilization was necessary since tissue extracts in $0.2 \mathrm{~mol} / 1$ acetic acid frequently caused non-specific inhibition of GIP in the radioimmunoassay.

\section{Immunoadsorption}

Preliminary studies indicated that immunoreactive GIP can be removed from rat gut extracts by gel filtration on Sephadex G 50 superfine columns. However, since it was unclear whether additional factors with insulinotropic activity would be lost if the GIP-containing fractions of the column were discarded, the method of immunoadsorption of GIP to a C-terminal specific antibody immobilized on Sepharose beads has been used. The IgG fraction of GIP antibody GÖ $5 / 76 / 9$ was prepared using the caprylic acid method of Steinbuch and Audran [16]. Sepharose 4B (Pharmacia, Uppsala, Sweden) was activated by $\mathrm{CNBr}\left(33 \mathrm{mg} \cdot \mathrm{ml} \mathrm{CNBr}^{-1} \cdot \mathrm{g}\right.$ wet Sepharose $\left.{ }^{-1}\right)$ [17]. The activation was performed at $\mathrm{pH} 11$ over $10 \mathrm{~min}$ and subsequently washed with ice-chilled destilled water and $0.1 \mathrm{~mol} / 1 \mathrm{NaHCO}_{3}$. The activated Sepharose beads were mixed with the antibody solution (2 $\mathrm{g} \mathrm{CNBr}-$ activated Sepharose beads with $1 \mathrm{ml}$ antibody solution containing approximately $3 \mathrm{mg} / \mathrm{ml}$ protein), stirred gently at $4^{\circ} \mathrm{C}$ over $20 \mathrm{~h}$ and the beads packed into a small column $(0.5 \times 7 \mathrm{~cm}$ - equivalent to $1.2 \mathrm{ml}$ of original antiserum). The columns were washed with $0.14 \mathrm{~mol} / 1 \mathrm{NaCl}$, $0.01 \mathrm{~mol} / 1 \mathrm{Tris}-\mathrm{HCl}(\mathrm{pH} 8.6), 0.04 \mathrm{~mol} / 1$ phosphate buffer (pH 6.5) and subsequently with $1 \mathrm{~mol} / 1$ ethanolamine $(\mathrm{pH} 8)$ for $16 \mathrm{~h}$ at $4{ }^{\circ} \mathrm{C}$. The washing procedure with ethanolamine was necessary to minimize non-specific adsorption of GIP to Sepharose beads and to prevent removal of non-immunoreactive incretins on either column. Control columns were prepared in the same way with rabbit IgG fractions containing no GIP antibody. By using ${ }^{125} \mathrm{I}$-GIP, approximately $75-80 \%$ of the radioactivity was bound to the Sepharose beads, while the control Sepharose did not bind radioactivity to any appreciable extent $(<8 \%)$. Lyophilized rat gut extracts were resuspended with $0.04 \mathrm{~mol} / 1$ phosphate buffer $(\mathrm{pH} 6.5)$ and the samples were applied on columns equilibrated with the same buffer solution and eluted at $5 \mathrm{ml} / \mathrm{h}$. Absorbed GIP peptides were eluted with $15 \mathrm{ml} 0.1 \mathrm{~mol} / 1$ acetic acid followed by $10 \mathrm{ml}$ distilled water. After three passages on average GIP was cleared from the gut extract solution to $>96 \%$. The GIPfree extract was lyophilzed and stored at $-20^{\circ} \mathrm{C}$. The lyophilized extract was reconstituted for infusion in appropriate amounts of $0.14 \mathrm{~mol} / 1 \mathrm{NaCl}$ to give a final protein concentration of $4.5 \mathrm{mg} / \mathrm{ml}$. Aliquots were taken for measurement of GIP and protein. The GIPcontaining gut extracts of the control Sepharose columns were diluted serially to give nominal concentrations of $400,200,100,50 \mathrm{pg} / \mathrm{ml}$ and added to duplicate tubes interlocked with a standard curve under usual conditions to determine parallelism with pure porcine standards.

\section{Laboratory Analysis}

Blood glucose was measured in duplicate on each sample by the glucose oxidase method. Immunoreactive insulin and immunoreactive GIP were determined within 4 weeks of the experiments in each plasma sample. Because the size of the samples was small, $50 \mu \mathrm{l}$ of plasma was measured in the radioimmunoassay for insulin and GIP, respectively. Plasma insulin was determined according to the method of Melani et al. [18] using rat insulin as standard. The incubation products were separated by polyethylenglycol 6000 (PEG6000, Serva, Heidelberg, FRG); the sensitivity of the assay was $6 \mathrm{mU} / \mathrm{I}$. Estimation of plasma immunoreactive GIP was performed according to the methods of Kuzio et al. [19] with some modifications [20]. The antiserum GÖ 5/76/9 was used throughout the study. The characterization of this antiserum has been described elsewhere [21]; it reacts with the mid C-terminal region of the GIP molecule [22]. At a final dilution of 1:70000, approximately $50 \%$ of $30 \mathrm{fg}$ of ${ }^{125}$ I-GIP added to each assay tube was bound in the absence of unlabelled GIP. This antiserum showed no cross-reactivity with secretin, cholecystokinin-33, gastrin, glucagon, gut, glucagon-like immunoreactivity I (GLI-I), motilin, neurotensin or somatostatin in concentrations up to $20 \mathrm{ng} / \mathrm{ml}$. The sensitivity of the assay allowed changes of $30 \mathrm{pg} / \mathrm{ml}$ immunoreactive GIP to be detected between individual adjacent plasma samples with $95 \%$ confidence. Non-specific binding was estimated in each assay for each animal experiment. Standard curves were set up with GIPfree rat plasma prepared by charcoal treatment of pooled fasting rat plasma. Antiserum GÖ 5/76/9 recognizes two major immunoreactive forms of GIP when analysing human plasma samples by gel permeation chromatography on Sephadex G 50 superfine columns. One fraction run in the range of pure porcine GIP, the other fraction has a putative molecular weight of 7500-8000 daltons. Since only the 5000 mol.wt. compound is found in rats [23,24], the estimation of the relative proportions of both compounds was not necessary in this study. Serial dilution curves of ${ }^{125}$ I-labelled porcine GIP in GIP-free rat plasma as tracer dilution curve, of GIP-containing rat plasma in GIP-free rat plasma as plasma dilution curve and of GIP-containing rat gut extract in GIP-free rat plasma as extract dilution curve were superimposable, indicating similar immunoreactivity of rat GIP and porcine GIP.

The within-assay precision, as expressed by coefficient of variation of 12 replicates of a plasma sample containing $400 \mathrm{pg} / \mathrm{ml}$ 


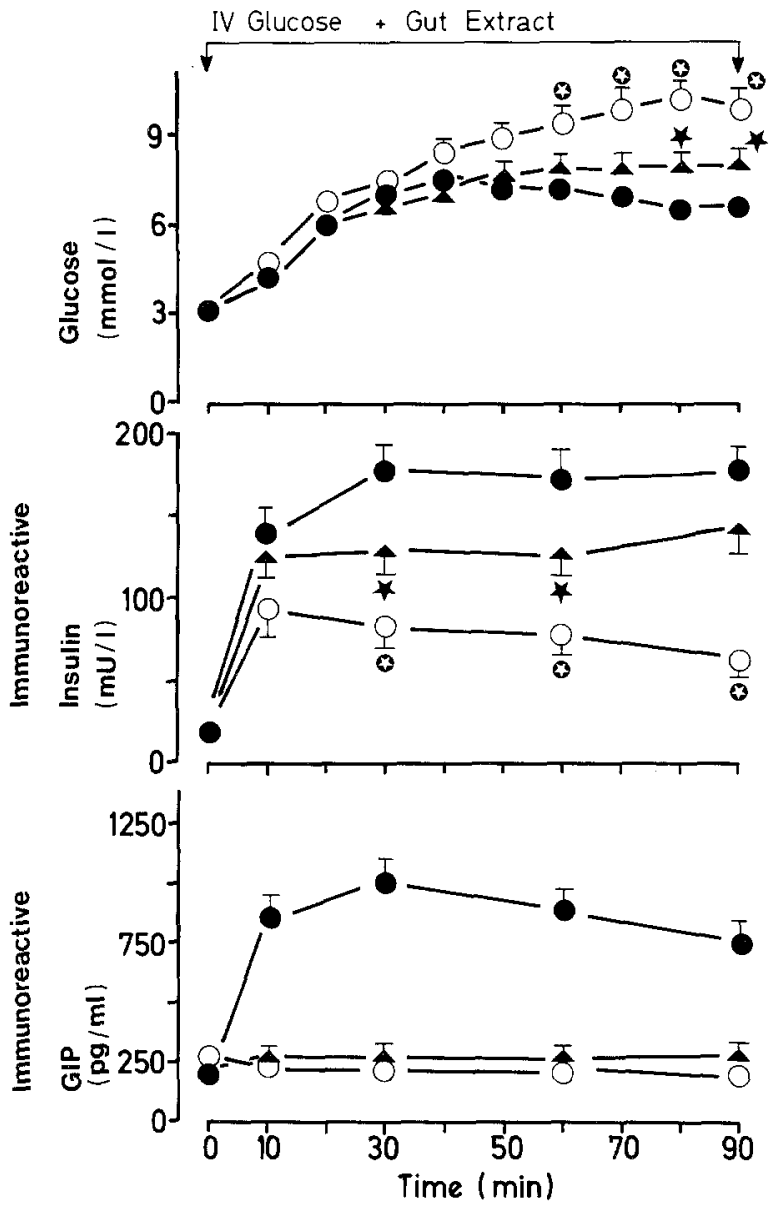

Fig. 1. Effect on plasma levels of glucose, immunoreactive insulin and immunoreactive GIP in rats following an IV glucose load $\left(1 \mathrm{~g} \cdot \mathrm{kg}^{-1}\right.$. $\left.\mathrm{h}^{-1}\right)(\mathrm{O}-\mathrm{O})$, IV glucose plus gut extract $(-0)$, or IV glucose plus GIP-free gut extract ( $\Delta-\mathbf{\Lambda}$ ). GIP was removed from the intestinal extracts by means of immunoadsorption. Both the GIP-containing and the GIP-free extracts were adjusted to give an infusion rate of $37 \mathrm{mg}$ protein $\cdot \mathrm{kg}^{-1} \cdot \mathrm{h}^{-1}$. Each curve represents the mean + SEM of 12 experiments. $*=p<0.05$ between GIP-free and GIP-containing extracts. $0=p<0.02$ between the control animals receiving glucose alone and the group receiving GIP-free gut extracts

immunoreactive GIP, was $7.9 \%$, the interassay variance during this study was $11.7 \%$. Radioimmunoassay measurements were performed. in three assays to minimize the influence of any interassay error. The GIP-binding capacity of antiserum-treated rat plasma was estimated as described elsewhere [25]. The rat plasma samples after administration of antiserum were serially diluted $(1: 8,1: 16,1: 32,1: 64,1: 128$ and $1: 256)$ in the assay buffer that was used for the radioimmunoassay. An aliquot of each dilution $(100 \mu \mathrm{l})$ was then incubated in the presence of trace amounts of ${ }^{125} \mathrm{I}$-GIP under standard assay conditions and the proportion of antibody-bound and antibody-free ${ }^{125} \mathrm{I}$ GIP identified by dextran-coated charcoal. The determination of antibody binding of GIP by undiluted rat plasma was made up by extrapolating the percentage binding of the antibody to zero dilution. Usually $84 \pm 3.4 \%$ of the labelled GIP was bound at excess antibody. Ninety min after bolus injection of $300 \mu \mathrm{l} \mathrm{GIP}$ antiserium, the percentage of unbound GIP was 5.9\%.

\section{Statistical Analysis}

All values are presented as mean \pm SEM. Student's t-tests for unpaired values were performed and $p<0.05$ was considered statistical-
Table 1. Integrated responses of plasma levels of glucose, immunoreactive insulin and immunoreactive GIP to an IV glucose load, IV glucose plus GIP-containing gut extract and IV glucose plus GIP-free gut extract

\begin{tabular}{llll}
\hline & \multicolumn{3}{l}{ Integrated responses (at 90 min) } \\
\cline { 2 - 4 } & $\begin{array}{l}\text { Glucose } \\
(\mathrm{mol} / \mathrm{l})\end{array}$ & $\begin{array}{l}\text { Immunoreac- } \\
\text { tive insulin } \\
(\mathrm{mU} / \mathrm{ml})\end{array}$ & $\begin{array}{l}\text { Immuno- } \\
\text { reactive } \\
\mathrm{GIP}(\mathrm{ng} / \mathrm{ml})\end{array}$ \\
\hline $\begin{array}{l}\text { IV glucose load } \\
\left(1 \mathrm{~g} \cdot \mathrm{kg}^{-1} \cdot \mathrm{h}^{-1}\right)\end{array}$ & $0.53 \pm 0.04$ & $4.52 \pm 0.37$ & $-2.11 \pm 0.24$ \\
$\begin{array}{l}\text { IV glucose }+ \\
\text { GIP-containing }\end{array}$ & $0.28 \pm 0.02^{\mathrm{a}, \mathrm{b}}$ & $13.67 \pm 0.92^{\mathrm{a}, \mathrm{b}}$ & $53.94 \pm 5.66^{\mathrm{a}, \mathrm{b}}$ \\
$\begin{array}{l}\text { gut extract } \\
\text { IV glucose }+\end{array}$ & $0.36 \pm 0.02^{\mathrm{c}}$ & $9.07 \pm 0.75^{\mathrm{c}}$ & $1.06 \pm 0.14$ \\
$\begin{array}{l}\text { GIP-free } \\
\text { gut extract }\end{array}$ & & & \\
\hline
\end{tabular}

Results expressed as mean + SEM $(n=12)$. GIP was removed from the extracts by immunoadsorption.

${ }^{a} p<0.005$ or less, significant difference between IV glucose versus IV glucose plus GIP-containing gut extract; ${ }^{b} p<0.02$, significant difference between IV glucose plus GIP-containing gut extract versus IV glucose plus GIP-free gut extract; ${ }^{c} p<0.05$, significant difference between IV glucose versus IV glucose plus GIP-free gut extract

ly significant. Integrated responses to the corresponding loads (IV glucose, IV glucose + gut extract etc.) for blood glucose, plasma immunoreactive insulin and immunoreactive GIP were calculated from the sum of the products of the mean plasma concentrations during each time period multiplied by the number of minutes in the time period minus the product of the basal value multiplied by the total number after the load.

\section{Results}

\section{Comparison of the Insulinotropic Action of Rat Gut Extract Before and After Removal of GIP by Immunoadsorption (Fig. 1)}

Following the IV glucose load $\left(1 \mathrm{~g} \cdot \mathrm{kg}^{-1} \cdot \mathrm{h}^{-1}\right)$, blood glucose levels rose continuously from a mean basal level of $3.4 \pm 0.3 \mathrm{mmol} / 1$ to a peak of $11.0 \pm 0.8 \mathrm{mmol} / \mathrm{l}$ at $80 \mathrm{~min}$. After a combined infusion of glucose and rat gut extract passed through the Sepharose $4 B$ control columns at a constant infusion rate of $37 \mathrm{mg}$ protein. $\mathrm{kg}^{-1} \cdot \mathrm{h}^{-1}$ corressponding to $0.9 \mu \mathrm{g}$ immunoreactive GIP $\cdot \mathrm{kg}^{-1} \cdot \mathrm{h}^{-1}$, significant inhibition of the glucose increment was seen between 60 an $90 \mathrm{~min}$. The GIP-free gut extract, also infused at a protein concentration of $37 \mathrm{mg} \cdot \mathrm{kg}^{-1} \cdot \mathbf{h}^{-1}$, lowered blood glucose levels significantly between 70 an 90 min when compared with glucose infusion alone. However, the glucose levels were significantly higher than the comparable levels of glucose plus GIP-containing gut extract at 80 and $90 \mathrm{~min}$.

Plasma insulin rose briskly to $97 \pm 10 \mathrm{mU} / 1$ at 10 min after IV glucose and declined slightly thereafter. When glucose and the GIP-containing gut extract were infused together the insulin response was nearly doubled reaching concentrations of $178 \pm 20 \mathrm{mU} / 1$ at $30 \mathrm{~min}(p<0.005)$ and $171 \pm 18 \mathrm{mU} / 1$ at $90 \mathrm{~min}(p<$ 


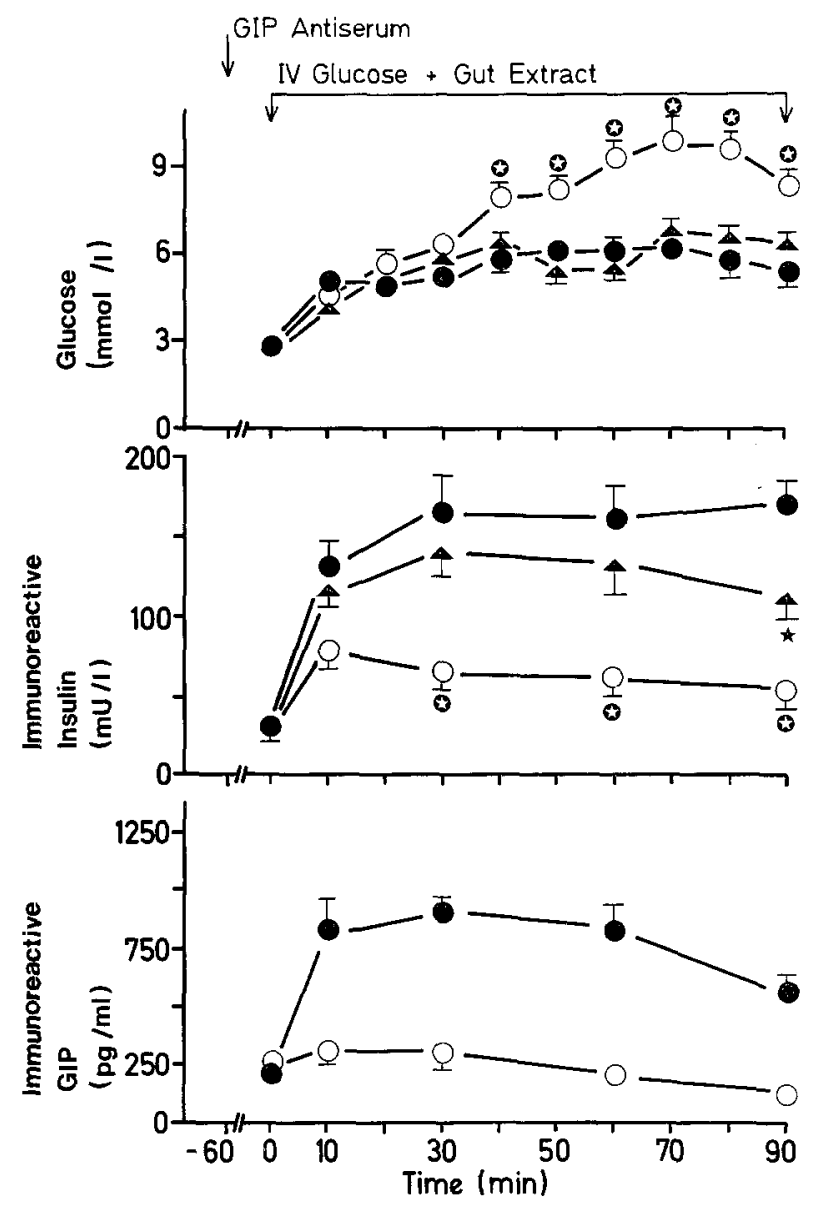

Fig. 2. Effect of pretreatment with GIP antiserum $(0.3 \mathrm{ml}$ bolus injection) on plasma levels of glucose, immunoreactive insulin and immunoreactive GIP in rats following an IV glucose load $\left(1 \mathrm{~g} \cdot \mathrm{kg}^{-1}\right.$. $\mathrm{h}^{-1}$ ) and concomitant infusion of rat gut extract ( extract was adjusted to give an infusion rate of $37 \mathrm{mg}$ protein $\cdot \mathrm{kg}^{-1}$. $\mathrm{h}^{-1}$ corresponding to $0.9 \mu \mathrm{g}$ immunoreactive GIP $\cdot \mathrm{kg}^{-1} \cdot \mathrm{h}^{-1}$. In control rats normal rabbit serum $(0.3 \mathrm{ml})$ was injected $60 \mathrm{~min}$ before the start of the infusion of glucose alone $\left(\mathrm{O}_{-} \mathrm{O}\right)$ ) or glucose plus gut extract (-), respectively. Each curve represents the mean + SEM of nine experiments. $*=0<0.05$ between the group receiving glucose plus gut extract and the antibody-treated group. $0=p<0.05$ between the control animals receiving glucose alone and the group receiving glucose plus gut extract after antibody treatment

0.001). By combining the IV glucose load with GIP-free extract, the insulin response was still significantly enhanced between 30 and 90 min compared with glucose alone, but the insulin levels were significantly smaller at 30 and 60 min than the levels obtained by infusion of glucose and GIP-containing gut extract $(130 \pm 11$ versus $178 \pm 2 \mathrm{mU} / 1$ at $30 \mathrm{~min}, p<0.05 ; 126 \pm 10$ versus $174 \pm$ $22 \mathrm{mU} / 1$ at $60 \mathrm{~min}, p<0.05$ ).

Plasma immunoreactive GIP rose from a basal level of $239 \pm 29 \mathrm{pg} / \mathrm{ml}$ to a peak of $983 \pm 137 \mathrm{pg} / \mathrm{ml}$ at $30 \mathrm{~min}$ after infusion of gut extract plus glucose, whereas no significant changes of plasma immunoreactive GIP were found in the control groups receiving IV glucose alone or IV glucose plus GIP-free gut extract.

The integrated insulin output due to the infusion of glucose was trebled when GIP-containing gut extract
Table 2. Integrated responses of plasma levels of glucose, immunoreactive insulin, immunoreactive GIP to an IV glucose load, IV glucose plus gut extract (containing $0.9 \mu \mathrm{g} \cdot \mathrm{kg}^{-1} \cdot \mathrm{h}^{-1}$ Immunoreactive GIP) and IV glucose plus gut extract plus GIP antibody

\begin{tabular}{llcl}
\hline & \multicolumn{3}{l}{ Integrated responses (at 90 min) } \\
\cline { 2 - 4 } & $\begin{array}{l}\text { Glucose } \\
(\mathrm{mol} / \mathrm{l})\end{array}$ & $\begin{array}{l}\text { Immunoreac- } \\
\text { tive insulin } \\
(\mathrm{mU} / \mathrm{ml})\end{array}$ & $\begin{array}{l}\text { Immuno- } \\
\text { reactive } \\
\mathrm{GIP}(\mathrm{ng} / \mathrm{ml})\end{array}$ \\
\hline $\begin{array}{l}\mathrm{IV} \text { glucose load } \\
\left(1 \mathrm{~g} \cdot \mathrm{kg}^{-1} \cdot \mathrm{h}^{-1}\right)\end{array}$ & $0.61 \pm 0.05$ & $5.63 \pm 0.41$ & $1.88 \pm 0.21$ \\
$\begin{array}{l}\text { IV glucose }+ \\
\text { gut extract }\end{array}$ & $0.33 \pm 0.03^{\mathrm{a}}$ & $12.40 \pm 0.85^{\mathrm{a}, \mathrm{b}}$ & $47.58 \pm 5.27^{\mathrm{a}}$ \\
$\begin{array}{l}\text { IV glucose }+ \\
\text { gut extract }+\end{array}$ & $0.32 \pm 0.03^{\mathrm{c}}$ & $9.68 \pm 0.68^{\mathrm{c}}$ & - \\
\begin{tabular}{l} 
GIP antibody \\
\hline
\end{tabular} & & & \\
\hline
\end{tabular}

Results expressed as mean $+\operatorname{SEM}(n=9)$. The antibody $(0.3 \mathrm{ml})$ was injected $60 \mathrm{~min}$ before start of the glucose infusion.

${ }^{a} \mathrm{p}<0.01$ or less, significant difference between IV glucose versus IV glucose plus gut extract; ${ }^{b} \mathrm{p}<0.05$, significant difference between IV glucose plus gut extract and IV glucose plus gut extract plus GIP antibody; ${ }^{\mathrm{c}} \mathrm{p}<0.02$, significant difference between IV glucose versus IV glucose plus gut extract plus GIP antibody

was added to the glucose infusion, while it was only doubled if GIP was removed from the extract (Table 1). However, the integrated insulin release under the latter condition was still significantly greater than after IV glucose alone. The integrated glucose responses were inversely related to the integrated insulin responses.

\section{GIP Antiserum Application Before Infusion of Rat Gut Extracts}

In Figure 2 the blood glucose and plasma levels of IRI and immunoreactive GIP after IV glucose $\left(1 \mathrm{~g} \cdot \mathrm{kg}^{-1}\right.$. $\mathrm{h}^{-1}$ ) and infusion of gut extract (37 mg protein $\cdot \mathrm{kg}^{-1}$. $\mathrm{h}^{-1}$ ) with and without GIP antiserum treatment are shown. After infusion of gut extract a significant smaller increase of blood glucose levels occurred than after glucose infusion alone. This suppression of the glucose response by gut extract was not significantly altered by pretreatment with GIP antiserum.

Only a small decrease of the gut extract-induced insulin increment was noted after injection of GIP antiserum which reached significance at $90 \mathrm{~min}(134 \pm 13$ versus $190 \pm 19 \mathrm{mU} / 1, p<0.02$ ). Consequently, the insulin response to glucose plus the gut extract, despite the antibody treatment at all points, was significantly higher than with glucose alone $(p<0.02)$. The increase of immunoreactive GIP levels in this series of experiments after infusion of rat gut extracts was similar to that seen in Figure 1.

The integrated insulin response became significantly smaller $(p<0.05)$ after GIP antiserum (Table 2$)$. However it was still significantly greater than after IV glucose alone. The unbound GIP 90 min after injection of GIP antiserum amounted to $5.9 \pm 0.7 \%$. 


\section{Discussion}

GIP is regarded as the main hormonal mediator of the enteroinsular axis [6]. When endogenous GIP, released after intraduodenal glucose, is neutralized by simultaneous infusion of GIP antiserum, the incretin effect of the glucose load is only partially abolished, indicating that factors other than GIP are present [13]. This could be the neural part of the enteroinsular axis [26, 27]. Neural mechanisms can be excluded by using gut extracts instead of an oral glucose load for demonstrating an incretin effect.

The present investigation shows that rat gut extracts exert an insulinotropic activity even after removal of GIP by immunoadsorption. The peak plasma GIP levels (approximately $1000 \mathrm{pg} / \mathrm{ml}$ ) produced by infusion of the gut extracts are in a range similar to the GIP concentrations observed after intraduodenal glucose application [13]. The intravenous glucose load was used to increase blood glucose levels above the threshold of $6.6 \mathrm{mmol} / 1$ for the insulinotropic action of GIP to become operative [28]. A threefold rise above the insulin concentration after glucose alone was produced by infusion of gut extract. After removal of GIP by immunoadsorption only $50 \%$ of the incretin activity of the gut extracts was lost, suggesting the existence of further humoral gut factors with insulinotropic activity.

Immunoadsorption was the method chosen to remove specifically GIP from gut extracts. The disadvantage of this method is that only GIP molecules related to porcine GIP are bound. However, the displacement studies with serially diluted rat gut extracts suggest that rat GIP is similar to that extracted from porcine gut and, that rabbit GIP antiserum, raised against porcine GIP, recognizes and binds rat intestinal GIP. On the other hand, the possibility has to be considered that molecular species of rat GIP exist in which the mid C-terminal region of the porcine GIP molecule is masked or absent and that therefore the so-called GIP-free gut extracts might include bioactive GIP fragments.

The insulinotropic activity of gut extracts was also preserved after injection of GIP antiserum. Under these circumstances about $30 \%$ of the insulin release triggered by gut extract infusion was inhibited. In previous experiments it has been shown that the same amount of GIP antibody abolished the insulinotropic effect of exogenous porcine GIP [13].

Several gut peptides, such as gastrin, cholecystokinin, secretin, motilin or vasoactive intestinal polypeptide, may be responsible for the persistent incretin effect after removal of GIP. Exogenous gastrin has been shown to augment glucose-induced insulin secretion [29] but in studies with patients before and after antral resection it has been demonstrated that gastrin contributed little if anything to the insulin response following oral glucose [30]. Neither motilin nor vasoactive intestinal polypeptide had a significant effect on glucosestimulated insulin release in the rat [31]. Physiological concentrations of secretin do not enhance insulin secretion [32]. In additions, the role of cholecystokinin as a physiological incretin candidate has been questioned [33]. Alternatively, it cannot be dismissed that gastrin, secretin and cholecystokinin may have an incretin effect if combined together as is the case in the GIP-free gut extracts in the present study.

Besides the defined gut peptides, several not yet identified insulinotropic peptide fractions of the gut have been described [31, 34-37]. Further investigations are needed to clarify whether the insulinotropic activity of our GIP-free gut preparation is related to one of these undefined factors. In preliminary chromatographic studies on Sephadex G 50 columns, we found the bulk of GIP-free insulinotropic material running behind the ${ }^{125} \mathrm{I}$-GIP, indicating that on a molecular weight basis most of these factors are smaller than GIP.

We conclude from this and an earlier study [13] that GIP is not the exclusive hormonal incretin candidate. Additional factors with insulinotropic activity may be released in response to oral glucose. This conclusion is supported by the observation that exogenous GIP and IV glucose given in concentrations to mimick the situation of an oral glucose load do not evoke as much insulin as oral glucose [38].

Acknowledgements. The authors wish to thank Mrs. K. Illmer and Ms. B. Berning for their expert technical assistance. This work was supported by the Deutsche Forschungsgemeinschaft, Bonn-Bad Godesberg, grant $\mathrm{Cr} 20 / 17$.

\section{References}

1. La Barre J, Still EU (1930) Studies on the physiology of secretin. III. Further studies on the effects of secretin on the blood sugar. Am J Physiol 91: 649-653

2. McIntyre C, Holdsworth CD, Turner DS (1964) New interpretation of oral glucose tolerance. Lancet 2: 20 21

3. Elrick H, Stimmler L, Hlad CJ, Arai Y (1964) Plasma insulin responses to oral and intravenous glucose administration. J Clin Endocrinol Metab 24: 1076-1082

4. Dupré J (1964) An intestinal hormone affecting glucose disposal in man. Lancet 2: 672-673

5. Unger RH, Eisentraut AM (1969) Entero-insular axis. Arch Intern Med 123: 261-266

6. Creutzfeldt W (1979) The incretin concept today. Diabetologia 16: $75-85$

7. Dupré J, Ross SA, Watson D, Brown JC (1973) Stimulation of insulin secretion by gastric inhibitory polypeptide in man. J Clin Endocrinol Metab 37: 826-828

8. Rabinovitch A, Dupré J (1974) Effects of gastric inhibitory polypeptide present in impure pancreozymin-cholecystokinin on plasma insulin and glucagon in the rat. Endocrinology 94: 1139-1144

9. Schauder P, Brown JC, Frerichs H, Creutzfeldt W (1975) Gastric inhibitory polypeptide: effect on glucose-induced insulin release from isolated rat pancreatic islets in vitro. Diabetologia 11: 483-484

10. Pederson RA, Brown JC (1976) The insulinotropic action of gastric inhibitory polypeptide in the perfused isolated rat pancreas. Endocrinology 99: 780-785

11. Brown JC, Dryburgh JR, Ross SA, Dupré J (1975) Identification and actions of gastric inhibitory polypeptide. Recent Progr Horm Res 31: 487-532 
12. Lauritsen KB, Holst JJ, Moody AJ (1981) Depression of insulin release by anti-GIP serum after oral glucose in rats. Scand J Gastroenterol 16: 417-421

13. Ebert R, Creutzfeldt W (1982) Influence of GIP antiserum on glucose-induced insulin secretion in rats. Endocrinology 111: 1601-1606

14. Porte, D Jr, Girardier L, Seydoux J, Kanazawa Y, Posternak Y (1973) Neural regulation of insulin secretion in the dog. J Clin Invest $52: 210-214$

15. Fischer U, Hommel H, Ziegler M, Jutzi E (1972) The mechanism of insulin secretion after oral glucose administration. III. Investigations on the mechanism of a reflectoric insulin mobilization after oral stimulation. Diabetologia 8: 385-390

16. Steinbuch M, Audran R (1969) The isolation of IgG from mammalian sera with the aid of caprylic acid. Arch Biochem Biophys 134: $279-284$

17. Akanuma Y, Kuzya T, Hayashi M, Ide T, Kuzuya N (1970) Immunological reactivity of insulin to sepharose coupled with insulin-antibody - its use for the extraction of insulin from serum. Biochem Biophys Res Commun 5: 947-953

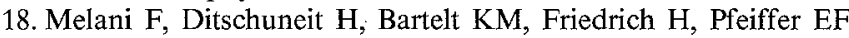
(1965) Über die radioimmunologische Bestimmung von Insulin im Blut. Klin Wochenschr 43: 1000-1006

19. Kuzio M, Dryburgh JR, Malloy KM, Brown JC (1974) Radioimmunoassay for gastric inhibitory polypeptide. Gastroenterology $66: 357-364$

20. Creutzfeldt W, Ebert R, Willms B, Frerichs H, Brown JC (1978) Gastric inhibitory polypeptide (GIP) and insulin in obesity: increased response to stimulation and defective feedback control of serum levels. Diabetologia 14: 15-24

21. Ebert R, Illmer K, Creutzfeldt W (1979) Release of gastric inhibitory polypeptide (GIP) by intraduodenal acidification in rats and humans and abolishment of the incretin effect by GIP-antiserum in rats. Gastroenterology 76:515-523

22. Flaten O (1981) Radioimmunoassay of gastric inhibitory polypeptide (GIP) and the effect of intraduodenal acidification on glucose-stimulated and unstimulated GIP release in humans. Scand $\mathbf{J}$ Gastroenterol 16: 545-554

23. Finke U, Ebert R, Creutzfeld W (1978) Different forms of immunoreactive gastric inhibitory polypeptide (IR-GIP) in human serum and intestinal mucosa. Diabetologia 15:232 (Abstract)

24. Gespach C, Bataille D, Jarousse C, Rosselin G (1979) Ontogeny and distribution of immunoreactive gastric inhibitory polypeptide (IR-GIP) in rat small intestine. Acta Endocrinol 90: 307-316

25. Goyal RK, McGuigan JE (1976) Is gastrin a major determinant of basal lower esophageal sphincter pressure? J Clin Invest 57 : 291-298

26. Siegel EG, Trimble ER, Renold AE, Berthoud HR (1980) The im- portance of preabsorptive insulin release on oral glucose tolerance: studies in pancreatic islet transplanted rats. Gut 21: 1002-1009

27. Woods SC, Porte D Jr (1974) Neural control of the endocrine pancreas. Physiol Rev 54: 596-619

28. Andersen DK, Elahi D, Brown JC, Tobin JD, Andres R (1978) Oral glucose augmentation of insulin secretion. Interactions of gastric inhibitory polypeptide with ambient glucose and insulin levels. J Clin Invest 62: 152-161

29. Rehfeld JF, Stadil F (1973) The effect of gastrin on basal and glucose stimulated insulin secretion in man. J Clin Invest 52: 1415-1426

30. Hayes JR, Ardill J, Buchanan KD (1975) Gastrin and insulin release. Diabetologia 11: 89-92

31. Turner DS, Etheridge L, Marks V, Brown JC, Mutt V (1974) Effectiveness of the intestinal polypeptides, IRP, GIP, VIP and motilin on insulin release in the rat. Diabetologia 10:459-463

32. Fahrenkrug J, Schaffalitzky de Muckadell OB, Kühl C (1978) Effect of secretin on basal- and glucose-stimulated insulin secretion in man. Diabetologia 14: 229-234

33. Jensen SL, Rehfeld JF, Holst JJ, Nielsen OV, Fahrenkrug J, Schaffalitzky de Muckadell, OB (1981) Secretory effects of cholecystokinins on the isolated perfused porcine pancreas. Acta Physiol Scand 111: 225-231

34. Moody AJ (1977) Insulin releasing polypeptides. In: Bajaj JS (ed) Diabetes, Internationel Congress Series 413. Excerpta Medica, Amsterdam, pp 76-82

35. Turner DS, Shabaam A, Etheridge L, Marks V (1973) The effect of an intestinal polypeptide fraction on insulin release in the rat in vitro and in vivo. Endocrinology 93: 1325-1328

36. Zermatten A, Felber J-P (1974) Sensitivity to glucose of an intestinal factor stimulating insulin release. Horm Metab Res 6:272--274

37. Levin SR, Phelevanian MZ, Lavee AE, Adachi RI (1979) Secretion of an insulinotropic factor from the isolated, perfused rat intestine. Am J Physiol 236: E710-E720

38. Sarson DL, Wood SM, Holder D, Bloom SR (1982) The effect of glucose-dependent insulinotropic polypeptide infused at physiological concentrations on the release of insulin in man. Diabetologia $22: 33-36$

Received: 2 September 1982

and in revised form: 4 February 1983

Professor Dr. med. W.Creutzfeldt

Medizinische Universitätsklinik

Robert-Koch-Straße 40

D-3400 Göttingen, FRG 